\title{
Kernos
}

Revue internationale et pluridisciplinaire de religion

grecque antique

32 | 2019

Varia

\section{Where Dreams May Come: Incubation Sanctuaries in the Greco-Roman World}

\section{Rebecca Van Hove}

\section{(2) OpenEdition}

\section{Journals}

Electronic version

URL: https://journals.openedition.org/kernos/3213

DOI: 10.4000/kernos.3213

ISSN: 2034-7871

\section{Publisher}

Centre international d'étude de la religion grecque antique

\section{Printed version}

Date of publication: 1 December 2019

Number of pages: $347-350$

ISBN: 978-2-87562-229-7

ISSN: 0776-3824

\section{Electronic reference}

Rebecca Van Hove, "Where Dreams May Come: Incubation Sanctuaries in the Greco-Roman World", Kernos [Online], 32 | 2019, Online since 01 October 2019, connection on 01 February 2022. URL: http:// journals.openedition.org/kernos/3213 ; DOI: https://doi.org/10.4000/kernos.3213

This text was automatically generated on 1 February 2022

Kernos 


\title{
Where Dreams May Come: Incubation Sanctuaries in the Greco- Roman World
}

\author{
Rebecca Van Hove
}

\section{REFERENCES}

Gil H. RENBERG, Where Dreams May Come: Incubation Sanctuaries in the Greco-Roman World, Leiden/Boston, Brill, 2017. 2 vol. $16 \times 24 \mathrm{~cm}$, lxix+1046 p. (Religions in the Graeco-Roman World, 184). ISBN : 978-90-04-29976-4.

1 That Gil Renberg can preface his weighty two-volume study of incubation in the ancient world with a note that it developed as a side project to two other books he is writing (also on dreams in antiquity) demonstrates the richness of the topic of ancient dreaming and its relative recent neglect in scholarship. In Where Dreams May Come, Renberg examines incubation - the practice of sleeping in a deity's sanctuary in order to receive a god-sent dream - in the Ancient Near East, the Ancient Greek world, Pharaonic and Greco-Roman Egypt, and Late Antique Christianity. His focus lies squarely on Greece and Egypt, whereas the Ancient Near East comes in to play primarily in the search for the origin of incubation and Late Antiquity makes an appearance only in two appendices. The work is a thorough and masterful study which adds significantly to our understanding of incubation and raises questions regarding what this practice can tell us more broadly about divination, religion, and medicine in the ancient world.

Volume One, comprising three parts, includes the bulk of the source material. Part 1 commences with an introductory chapter defining incubation, and a second chapter on the early development of the practice. Renberg is comprehensive in his examination of Near Eastern sources, covering Sumerian, Babylonian, Hittite, Ugaritic and Hebrew texts, as well as Pharaonic and pre-Hellenic Egypt. Part 2 focuses on Greek cults. 
Chapter 3 scrutinises Asklepios, the god most connected to incubation, and his many temples in which incubation was carried out as a healing practice. Chapter 4 continues the interest in therapeutic divination but looks at other Greek cults, while Chapter 5 examines the evidence for divinatory incubation in the Greek world. Part 3 moves on to Egyptian and Greco-Egyptian cults. Its chapters are organised either by deity or particular cult site, whereby Chapter 6 focuses on Sarapis and Isis, Chapter 7 on the site of Saqqara and its "House of Osiris-Apis", Chapter 8 on the deities Amenhotep and Imhotep, and finally Chapter 9 on evidence for incubation at other Egyptian cults. Volume Two consists exclusively of 17 appendices, some of them thematic studies that address in depth a particular issue relevant to multiple cultic sites: one of these, for instance, considers fertility incubation, while others deal with questions such as the language of pre-incubatory prayer and whether the sexes were separated during incubation. Other appendices function like catalogues: Appendix 1 lists sites wrongly or dubiously linked to incubation; Appendix 16 offers a bibliographical survey of the sources for incubation in Late Antique Christianity. The volume concludes with a general index and a usefully detailed index locorum. It has an impressive number of high-quality colour images and maps, and the publisher is to be commended for supporting the use of such visual material.

3 As it is impossible to discuss Renberg's whole study in detail, I concentrate my review on a few specific chapters in Parts One and Two, before making some larger points about the work as a whole.

4 In Chapter Two Renberg tackles the early history of incubation, focusing in particular on the question of who incubated. As he shows, in our oldest sources from the ancient Near East the practice was largely dominated by kings and priests, the latter often on behalf of the former. Evidence for non-elite incubation in the ancient Near East is scarce, limited to a few Hittite texts which may potentially refer to incubation, while in Egypt the first certain sources for non-elite incubation date only from the Ptolemaic period. Examining how incubation developed as a practice, Renberg advocates for the importance of recognising a distinction between two types of incubation: what he calls 'therapeutic' and 'divinatory'. The first describes the practice of the sick and injured seeking medical attention at incubation sanctuaries, whereby the god would be expected to heal the incubants in their sleep or provide medical advice to them in their dreams. Divinatory incubation, by contrast, concerns the practice of soliciting dreams about matters other than health concerns, whether private or public. Renberg convincingly demonstrates the usefulness of this terminology to distinguish between two practices which, while sharing many of the same logistics and characteristics, remain distinct in certain important respects. He argues that divinatory incubation generally developed before the therapeutic kind arose - in Greece as for the ancient Near East.

5 A second important point Renberg makes in Part One concerns the development of incubation across the ancient world. Treating the issue of where the practice originated and how it spread, Renberg is cautious to point out that it is not possible to draw a direct line between ancient Near Eastern incubation and later practices in Greece and Egypt, although he believes the latter were at least "indirect recipients" of such practices, regarding incubation as a "cultural inheritance from the ancient Near East." He believes the practice was a religious tradition native to Egypt - despite the rather limited and late evidence (not before the end of the Late Period, 664-332 BCE) - before 
Hellenic influences disseminated incubation more widely and opened it up to a wider group of people.

The lack of physical remains from Near Eastern or Egyptian sanctuaries where incubation was practiced or any visual material representations means we are reliant on often fragmentary texts, whose contexts are frequently unclear. Renberg offers detailed and deft analysis of these sources and skillfully identifies their uncertainties. At times, however, he seems perhaps too quick to accept interpretations which support the presence of incubation: for example, he claims that a sixth-century unpublished Demotic papyrus, PHeidelberg Dem.5, "casts doubt" on the theory that therapeutic incubation came from Greece to Egypt but then later plainly admits that the place where the dream in this source was solicited is unknown, "leaving open the possibility that it describes a private ritual" - and thus no incubation at all.

7 Part Two of the book centres on the Greek world. Renberg's goal, of identifying sites at which incubation took place, is apparent in the opening chapter's structure : he first discusses in depth the archaeological evidence at different Asklepieia potentially connected to incubation, taking each site in turn, and then the written and iconographical sources for each site, before offering a summary of Asklepios' modus operandi. The question here hinges on how far we can assume practices evinced at one site (e.g. payment for services, regulations regarding ritual purity, or the type of cures suggested) were similarly organised at others. Renberg is often careful not to extrapolate too much from limited evidence. In his summaries for each individual site, he frequently - and often frustratingly - emphasizes the negative results, highlighting over and over the limits of sources and the problematic uncertainty entailed, rather than offering constructive statements on what we can say about incubation at these various cult sites.

8 Nonetheless, Renberg impressively negotiates the archaeological evidence and the textual sources to reconstruct the development of Greek incubation sanctuaries over time, complicated as it is by the broad chronology of the sources and by the fact that, as he accurately explains, archaeological traces cannot provide definitive proof of the presence of the practice, if not accompanied by written sources or reliefs. Renberg is critical of attempts to assimilate the presence of, for example, a stoa, buildings with halls, or water sources with incubation: he makes clear that the role of water in therapeutic incubation or incubation rituals especially is not well understood. As a result, he refutes, for instance, the identification of incubation at the Asklepieion of Corinth, Delos, Rome's Tiber Island, or the smaller Alipheira in Arcadia. He argues that assuming one has incubation wherever one has Asklepios, as often done in the past, is a problematic assumption - meaning there is no way to know how common incubation was. Both in the chapter on Asklepieia and the two following on incubation in Greece at other sites, Renberg makes very good use of lesser known sites, such as Lebena, Oropos, and Erythrai, to demonstrate the variety in practices found at different sanctuaries. He convincingly takes apart the assumption that at Oropos, where people incubated in the temple of Amphiaraos, incubation was always preceded by a compulsory animal sacrifice and further suggests this might have been the case for divinatory incubation but not the therapeutic kind, thereby offering a credible solution to a problem of conflicting sources. Renberg concludes that divinatory incubation was more widespread as a form of temple divination in ancient Greece than has often been recognised. 
9 In general, Renberg's chief purpose throughout the book is to establish where and how incubation took place in the ancient world. As already mentioned for the Greek context in Part 2, he takes a diachronic approach and offers a comprehensive analysis of every potential site for incubation, surveying both the archaeological and textual sources at each site and evaluating the reliability of these - often fragmentary or problematic sources. He is interested, too, in "illuminating the variations from cult to cult or site to site in terms of the ritual procedures and the sources that record these." In his introduction, he explicitly states that the book is not concerned with matters like "the deeper meaning or significance of the rituals associated with the practice, or the contents of dreams received in this manner". His goal is therefore very much focused on documenting where incubation took place and what happened at these sites.

10 This documentary approach is noticeable in the number and length of footnotes as well. It is not infrequent to find a spread of pages with less than six lines of main text between them, the rest of the space filled with notes. While adequate documentation is clearly important in general and heavy documentation is understandable given the impressive volume of sources discussed by Renberg, at times the reader has the impression that integration of some of the material relegated to the footnotes could have served his investigation well. One example is the analysis of the presence of physicians at sanctuaries of Asklepios, limited to a lengthy footnote. Surely this question, crucial to our understanding of the interplay between religion and medicine in ancient Greece, is relevant to any robust analysis of therapeutic incubation.

This arrangement of material leads me to a more general point about the objective of the book, which at times feels rather limited. While the range of sources, cultures, and sites discussed is impressive, such breadth in comprehensiveness can work to the detriment of depth. There are numerous occasions where Renberg's analysis does not go as far as one would have hoped. At times he offers only cursory discussion of issues which I would consider crucial to a wider understanding of incubation: for example, on the question of the identity of incubation deities - why did divinatory incubation only occur at cults of deities who were divinized mortals? What is the precise nature of the connection we observe between incubation and chthonic deities, a question only treated in a few paragraphs in the introduction? Other instances where a further analysis would have been welcome are found throughout the book: when Renberg states that there is no way to know how common incubation was or which factors led some Asklepieia to provide incubation while others did not, it is unfortunate that no answer is even attempted. Similarly, in the chapter on divinatory incubation in Greece, many of the sources Renberg cites concern incubation only by those who serve the polis in an official capacity - an intriguing suggestion concerning who was allowed to incubate, which would have merited further discussion and perhaps comparison with the limits on incubation found in the early Near Eastern sources. Of course, one would not expect easy or simple answers to any of the issues I raise here. Yet Renberg's reluctance even to sketch an evaluation does feel like he is, at times, shying away from the larger analytical questions on the purpose and meaning of incubation, and what this tells us about religion and society in the ancient world. The book's complete lack of a general conclusion demonstrates this too. The strong, dedicated focus on identifying primarily where incubation took place eclipses the more pressing and fascinating questions of why and how. Is it necessary to write a two-volume book, over a thousand 
pages, which does not even cover the function or purpose of the practice described in such glimmering detail? ${ }^{1}$

In short, Where Dreams May Come is a significant addition to the scholarship on ancient dreaming and the ritual of incubation, which will prove extremely useful as a reference work and as a catalogue to sources for the particular sanctuaries where incubation has been attested. The author succeeds in achieving what he set out to do. The study, as Renberg himself acknowledges, is "not intended to be the last word on incubation, but rather an attempt at providing scholars more solid footing on which to base their own studies of the practice." This is a great first step, but now a second step of further analysis awaits.

\section{NOTES}

1. An example of a different approach to the topic is found in H. von Ehrenheim (2015), Greek Incubation Rituals in Classical and Hellenistic Times (Kernos, Suppl. 29), which appeared in print too late for Renberg to take it into account. Von Ehrenheim's work demonstrates how the disparate and fragmentary sources for the technicalities of incubation can be brought together with an analysis of the social framework in which incubation rituals took place and the function of this religious practice within ancient Greek communities.

\section{AUTHORS}

\section{REBECCA VAN HOVE}

Collège de France / Université de Liège 